\title{
Post-modernism as the Decadence of the Social Democratic State
}

\author{
ARRAN GARE
}

ABSTRACT In this paper it is argued that the corresponding rise of post-modernism and the triumph of neo-liberalism are not only not accidental, the triumph of neo-liberalism has been facilitated by post-modernism. Post-modernism has been primarily directed not against mainstream modernism, the modernism of Hobbes, Smith, Darwin and social Darwinism, but against the radical modernist quest for justice and emancipation with its roots in German thought. The Social Democratic State, the principles of which, it is here argued, were articulated by Hegel, was a partial triumph of this radical modernism, realising a higher level of reciprocal recognition and overcoming much of the brutality of the Liberal State. Post-modernism is shown to be a manifestation of the decadence of the Social Democratic State, characterised by the disintegration of cognitive and ethical developments which have been the condition for people to form communities based on reciprocal recognition. In this regard it parallels the decadence which took place in ancient Rome, for similar reasons: both the Roman Empire and the social democratic state reduced people to passive recipients of the benefits of their societies. The implications of this are twofold. If social democracy is to be revived, it will require a struggle for 'strong' democracy; that is, for a major role for participatory democracy. On the other hand if people opt for the creation of confederations of genuinely democratic communities to replace the state, this will not be achieved by post-modern decadence but through the developments of cognitive forms and communities through which the recognition of people as free agents is institutionalised.

What is post-modernism? It is the rejection of core tenets of modernism and the embracing of post-modernity. What is modernism? It is embracing, promoting and contributing to the development of modernity. Post-modernity is the state of culture after the disintegration of modernity. All these terms are defined ultimately in relation to modernity. What then is modernity?

Modernity is the cultural era that began in Europe in the 15th, 16th and 17th centuries with the Renaissance, the Reformation, the triumph of the market economy over feudal social relations, the rise of science and the birth of liberal democracy. In the Enlightenment of the 18th century these developments were celebrated as the triumph of reason and in the 19th century this new order generated industrial capitalism. From its birth in Europe this culture and its associated social forms have come to dominate the world, creating the global market organised through a global system of nation states with governments purportedly representing the people of these nations. From the perspective of mainstream modernists, modernity has generated massive technological developments that 
have enabled humans to dominate nature as never before, liberated people from political, economic and social constraints and integrated the world into a global community. Although it was only promulgated (by Turgot) towards the end of the 18th century, this culture is integrated by the notion of progress. To believe in progress is to see humanity living out a story in which past, defective forms of knowledge, technology, art forms and social relations are being transcended. People are being liberated from oppressive traditions, diseases, shortages of food and housing and ushered into an increasingly exciting world of high technology, breaking down barriers of both space and time. The future portrayed by the dominant image of progress is one in which the entire world will eventually embrace liberal democracy upholding the sovereignty of the individual in the marketplace.

Radical (or counter-) modernists have a less rosy picture of the triumph of modernity. They tend to be more concerned about the illusory nature of freedom in liberal democracies, the brutality of industrial capitalism, the oppression of the working class, the suffering wrought by European imperialism and colonialism and the destructive impact of economic growth on traditional communities and the environment. The radical modernists have been the driving force behind communism and social democracy, opposition to imperialism and the creation of international organisations such as the United Nations. Modernity is upheld more for the future it promises than what it has achieved. To realise this potential the market must be severely constrained or replaced by social and political institution $\mathrm{s}$ that properly recognise the dignity of people, emancipate them from exploitative relationships and allow them to control their destinies. For radical modernists, there is a greater urgency to overcoming the defective forms of thought and institution $\mathrm{s}$ of the present. Correspondingly, there is an even greater commitment to progress. What is needed is more rationality, a creative rationality that will put an end to the exploitation of the Third World and of the working class and the alienation of people from their creative powers, from each other and from the rest of nature. To expose the illusions of the present such modernists uphold the value of developments in science, art and literature that bring into question taken-for-granted assumptions and ways of perceiving to reveal a deeper reality behind appearances. This is a reality within which radically new and better ways of life are possible. Radical thinkers, scientists and artists are celebrated as an avante-garde revealing the true nature of reality and leading humanity towards a better future.

Post-modernists are more fundamentally critical of modernity. Initially postmodernism was defined in opposition to the radical modernist cultural movements in art, literature and architecture that began in the 1890s and dominated high culture until the 1970s. Usually it was only in reaction to this modernism of high culture that post-modern theory was developed as an opposition to the broader culture of modernity. Post-modern theorists can be classified as 'deconstructive' or 'reconstructive'. Deconstructive post-modern theorists have not promoted opposition to modernism as a positive affirmation of a new set of ideas. Lyotard, for instance, did not attack the grand narratives that, he claimed, defined modernity, but described the post-modern condition as 'an incredulity towards metanarratives' ${ }^{1}$ and then

1. Jean François Lyotard, The Postmodern Condition: A Report on Knowledge, transl. Geoff Bennington and Brian Massumi (Minneapolis: University of Minnesota Press, 1984), p. xxiv. 
spelt out the implications of this incredulity. Foucault spoke of 'man' of the modern 'episteme' as an invention 'perhaps nearing its end'.2 And Baudrillard has been well described as 'a major cultural cartographer of the post-modern cosmos'. ${ }^{3}$ Such theorists are post-modernist in the sense that they tend to celebrate the exhaustion of modernism as something liberating. ${ }^{4}$ In the spirit of this exhaustion, deconstructive post-modern theorists engage in endless critique for its own sake, attacking all positive norms as inherently totalising. Reconstructive post-modern theorists by contrast consist of a group of scientists, philosophers and theologians associated with the tradition of process philosophy (for example, David Ray Griffin) and a group of neo-Marxists and radical feminists (for example, Steven Best, Douglas Kellner and Donna Haraway) who have augmented their radical modernist critiques of society with ideas taken from the 'poststructuralists'. They tend to see the differentiation of post-modern culture as a stage on the way from modernity to a radically new culture and, particularly in the case of process philosophers, are striving to create this new culture. As such they can be construed as proponents of an even more radical form of modernism. This differentiates them from and sets them at odds with the deconstructive post-modernists. Here my focus is on postmodern culture and the way deconstructive post-modern theory has supported it.

Why was the disintegration of modernism embraced by deconstructive postmodern theorists? By privileging certain discourses, ideas, works of art and individuals, modernism of all kinds was seen to be elitist and domineering. Modernism denigrates popular culture while promoting oppressive forms of thinking, architecture, town planning and social institutions. The deconstructive post-modernists represented themselves as more radical than radical modernists because they not only refused to accept such elitism; they also rejected the deeply rooted assumptions on which this elitism had been based. ${ }^{5}$ Deconstructive postmodern theorists opposed the totalising perspectives that failed to do justice to particulars. They exposed the taken-for-granted oppositions which enabled some people to dominate others: the notions of truth, identity, order, rational, being, etc., defining their opposites as lack, empowering those identified with the privileged terms while excluding those identified with their negations as unworthy of being taken seriously. They revealed behind the discourses purporting to discover the truth, the practices of subjection. They have shown how essentialist thinking has been used to support existing hierarchies of power-whether between male and female or between European and 'Oriental' (as in the work of Edward Said and the subaltern historians of India). ${ }^{6}$ They have shown how grand narratives in

2. Michel Foucault, The Order of Things (London: Tavistock, 1970), p. 387.

3. Nicholas Zurbrugg, 'Baudrillard, Modernism, and Postmodernism', in Douglas Kellner, ed., Baudrillard: A Critical Reader (Oxford: Blackwell, 1994), p. 2.

4. It should be noted that French 'poststructuralists' embraced by American post-modern theorists, with the exception of Lyotard, deny any relation to and are generally critical of postmodernism.

5. For a good critical overview of post-modern political and ethical theory, see Stephen K. White, Political Theory and Postmodernism (Cambridge: Cambridge University Press, 1991).

6. For a study of this, see Robert Young, White Mythologies: Writing History and the West (London: Routledge, 1990). 
upholding an end towards which history is moving have ranked people and societies according to how advanced they are, and then justified the subjection of those people defined as backward (or 'pre-modern'). By exposing these assumptions and the nature of the practices they have generated, deconstructive post-modernists have encouraged those who had been marginalised: women, gays, lesbians, ethnic minorities, 'orientals' and 'primitives' to express and assert themselves. Post-modernists would appear to have revived the tradition of anarchism suppressed by Marxism.

However, while deconstructive post-modern theorists have provided powerful critiques of various facets of society and their ascendancy has coincided with far greater tolerance for minorities than previously, the rise of post-modern culture has coincided with the revival of neo-liberal ideology and of a reinvigorated market economy entering a new phase of globalisation. The people who dominate the world have never been more secure in their belief in the grand narrative of economic progress. It now appears that post-modernity was an illusion. While deconstructive post-modernists might still hope for the disintegration of modernity, they can no longer claim this disintegration is underway. In fact the rise of post-modern culture has been associated with the massive concentration of economic and political power, the dissolving of the welfare state and the dissolution of not only communism but also of social democracy. What has disintegrated is the radical modernist vision of a future in which justice will be made to prevail over the imperatives of the market economy. What light does this throw on deconstructive post-modernism? Was the rise of post-modern culture and deconstructive post-modernism at the same time as the triumph of global capitalism and the disintegration of radical modernism merely a coincidence? And if it was not, was deconstructive post-modernism involved in the disintegration of radical modernism and the globalisation of capitalism? My contention is that postmodern culture is part of the decadence of social democracy and, to the extent that deconstructive post-modernism has undermined radical modernism and promoted this decadence, it has helped facilitate the triumph of neo-liberalism and the reinvigoration and globalisation of the market economy.

\section{Globalisation and Post-modernity}

To begin with, we need to reassess the claims made for post-modernity. With the reinvigoration of modernity in its neo-liberal form, it is becoming clear just how deluded was the belief that it was disintegrating. As Jonathon Friedman has argued, postmodernism was a response of members of the relatively affluent middle classes, classes that had developed in the social democratic states of the West, as they lost their privileged positions within the world economy. ${ }^{7}$ As politicians were transforming state institutions into administrative structures to serve the global market, these people were abandoning their quest to control their destinies, simultaneously, losing any sense of the future. Living in the present, defining themselves through their styles of consumption, they gave up the effort

7. See Jonathan Friedman, Cultural Identity \& Global Process (London: Sage, 1994). See also Arran Gare, Postmodernism and the Environmental Crisis (London: Routledge, 1995), ch. 1. 
to organise their experience and to orient themselves through narratives. Grand narratives, which represented them as losers rather than people at the cutting edge of world history, ceased to be entertained, let alone believed. It was the 'intellectuals' of this sub-class who embraced the neo-Nietzschean and neo-Heideggerian cultural critiques of 'poststructuralist' thinkers such as Lacan, Foucault and Derrida and their interpreters.

Pierre Bourdieu provides some insight into the attitudes of this new sub-class and its relation to post-modern theorists:

The students of bourgeois origins who have become academically downclassed, and who populate the arts faculties, especially in the new disciplines, are victims of verdicts which, like those of the school, appeal to reason and science in order to block off the paths leading (back) to power. They are spontaneously inclined to denounce science, power, the power of science, and above all perhaps a power which, like the triumphant technology of the moment, appeals to science in order to legitimate itself.

Bourdieu went on to describe how academics had responded to this:

[A] new bourgeois 'life-style' developed, making way for values excluded from the old, pre-war, neo-Kantian university ...-that is, desire, pleasure and 'anti-repressive' dispositions. All these themes which will be strongly orchestrated by all the philosophical avant-garde from Deleuze to Foucault, via Derrida ... not to mention the minor heresiarchs, more closely 'tuned in' to the new vulgate. ${ }^{8}$

Elsewhere Bourdieu provides a portrait of the products of this vulgate:

Guided by their anti-institutional temperament and the concern to escape everything redolent of competitions, hierarchies and classifications and, above all, of scholastic classifications, hierarchies of knowledge, theoretical abstractions or technical competences, these new intellectuals are inventing an art of living which provides them with the gratifications and prestige of the intellectual at the least cost; in the name of the fight against 'taboos' and the liquidation of 'complexes' they adopt the most external and most easily borrowed aspects of the intellectual life-style, liberated manners, cosmetic or sartorial outrages, emancipated poses and postures, and systematically apply the cultivated disposition to not-yet-legitimate culture (cinema, strip cartoons, the underground), to every-day life (street art), the personal sphere (sexuality, cosmetics, child-rearing, leisure) and the existential (the relation to nature, love, death). ${ }^{9}$

8. Pierre Bourdieu, Homo Academicus, transl. Peter Collier (Cambridge: Polity Press, 1984), p. xxvf.

9. Pierre Bourdieu, Distinction: A Social Critique of the Judgement of Taste, transl. Richard Nice (Cambridge, MA: Harvard University Press, 1984 [1979]), pp. $370 f$. 
Although Bourdieu was writing about France, with minor differences much the same developments have occurred in all western nations.

Now aging, with the social democratic state that supported their lifestyles disintegrating, such deconstructive post-modernists (with the exception of those who gained academic tenure in countries where it has not yet been abolished) have been completely marginalised. Yet they were far more significant than this sketch might suggest. To begin with, by gaining the symbolic power to define reality, these post-modernists helped undermine the semi-autonomous cultural fields and social and political institutions through which radical modernists had exerted their influence. In place of the quest for justice upheld as a grand narrative of emancipation-in opposition to the grand narrative of progress through the struggle for survival in the market, deconstructive post-modern theorists promoted an ethics and politics of liberation from all institutional constraints. Paradoxically, such thinking has often been accompanied by dogmatic assertions of what is right, characterised as 'political correctness'. So, in place of the quest to create political, social and economic structures and institutions that would recognise the full potential of people, enable them to control of their destinies and to express themselves in their work, post-modern cultural theorists censured discrimination on the basis of gender, race or sexual preferences and railed against any form of constraint on immediate gratification. Radical modernists were attacked for arrogance in claiming to speak for others in projecting new visions of the future. Deconstructive post-modernists often saw themselves as opposing the destructive imperatives of capitalism; but far from being a threat to the existing order, they reinforced its ethos. Bourdieu wondered whether 'the ethic of liberation is not in the process of supplying the economy with the perfect consumer whom economic theory has always dreamed of ....'. ${ }^{10}$ Not only were such people intent on consuming the latest offerings of the market, but also as consumers they dissociated themselves from the constraints of collective memories and expectations that in the past had insulated people from the images of the high life produced by the mass media.

Deconstructive post-modern theorists were symptomatic of a more general cultural transformation, a transformation that had been taking place in society for some time - as noted by a diversity of cultural theorists ranging from conservative sociologists such as Daniel Bell and Bernice Martin to the radical social theorists inspired by the Frankfurt Institute of Social Research. It had been taking place also in politics. Contempt for tradition and 'essentialism' is evident not only in the dismissal of the canons of art and literature and the privileged status of the discourses of philosophy and science, but in previously social democratic political parties. With total indifference to political traditions and the essence of left-wing politics, the leaders of these parties have abandoned completely the goals on which they were originally founded. What a study of this transformation suggests is that post-modernism is not merely the effect of the disintegration of the social democratic state confronted by the globalisation of the economy, but an essential part of this transformation. It is an expression of the decadence within the social democratic state.

10. Ibid., p. 371. 


\section{'Decadence', from Plato to Radding}

What is decadence? Decadence means 'falling away' or 'decay'. Book Eight of Plato's Republic offered the first analysis of decadence. Plato's analysis is based on his analysis of the mind or soul as a tripartite entity consisting of intellect, spirit and appetites. The intellect aspires to wisdom, the spirit strives for honour while the appetites drive people to acquisitive behaviour and sensuous gratification. Societies can be interpreted as in various stages of decay from an ideal society in which the intellect rules over spirit and the spirit rules over the appetites. Plato showed how a society of spirit without wisdom such as the Sparta tends to be displaced by the disciplined acquisitiveness characteristic of the Corinthians which in turn leads to undisciplined self-indulgence characteristic of the Athenians. The children of such societies reject all discipline and live for pleasure, holding that all pleasures are equal and should have equal rights. For such people:

the least vestige of restraint is resented as intolerable, till finally ... in their determination to have no master they disregard all laws, written and unwritten. ... They bend over their tables, like sheep with heads bent over their pasture and eyes on the ground, they stuff themselves and copulate, and in their greed for more they kick and butt each other .... ${ }^{11}$

With all constraints gone, tyrants dedicated to satisfying their every whim are able to rise to power. This social degeneration is associated with the degeneration of thinking. People lose first their ability to think dialectically, then their ability to think abstractly, and finally their ability to distinguish between appearances and reality.

Plato's portrait of decadence seems a good characterisation of a number of later social transformations, including the degeneration of Rome, the 14th century Italian City States, and Germany leading up to the triumph of Naziism. It has also been the starting point for a range of other analyses of decadence, including those of Vico, Gibbon, Hegel, Spengler and Toynbee. Plato measured the extent of decadence against a static and as yet unrealised ideal form of a Greek polis. Subsequent analysts of decadence have taken into account a far greater range of social and political organisations and have advanced historical, social and psychological insights beyond those of Plato.

Hegel's work is especially significant. Hegel construed history as a sequence of forms of subjective spirit (psychology) ${ }^{12}$ objective spirit (institutions of the state) and absolute spirit (art, revealed religion and philosophy), each moving to realise a higher level of development and then decaying as their internal contradictions became apparent and their unique potentials had been exhausted. ${ }^{13}$ His

11. Plato, The Republic, 564d. and 586a.

12. Various facets that were dealt with by Hegel under the headings 'anthropology', 'phenomenology' and 'psychology'.

13. Nietzsche's notion of decadence is an inversion of Plato's and Hegel's, just as his Genealogy of Morals is an inversion of Hegel's analysis of the dialectic of lord and slave. 
notion of the modern state as a form incorporating the achievements of yet transcending all previous forms, articulates the underlying principles that unfolded as the social democratic state to succeed the liberal democratic state of 19th century Britain. The most cogent defenders of the social democratic state (such as Habermas in Germany and Charles Taylor in Canada) belong to a tradition of social philosophers inspired directly or indirectly by Hegel. Hegel was the original radical modernist. The main targets of deconstructive post-modern theorists are Hegel and those he inspired, and their main source of inspiration is the antiHegelian tradition represented by Nietzsche and Heidegger. While post-modernists attack Hegelian thought as oppressive, post-modern culture can be interpreted in Hegelian terms (without necessarily accepting Hegel's idealism) as the decadence of the social democratic state as its contradictions have become manifest and people have ceased to be inspired by these principles.

However, to fully understand what is involved in this process we need to look at subsequent developments both of political philosophy and of what is involved in decadence. Aspects of the work of Habermas, Honneth and Bourdieu throw further light on social democracy as it has developed, while one of the most profound studies of decadence in recent years, Charles Redding's study of cognitive transformations in Europe between $400 \mathrm{AD}$ and $1200 \mathrm{AD}$ (utilising the ideas of Vico and Piaget) provides the means to understand the decay of social democracy. ${ }^{14}$

\section{Hegel and the Social Democratic State}

Hegel is well known for his claim in the preface to the Philosophy of Right that philosophy can provide no instruction for how the world ought to be. Philosophy only reveals the ideal when it has emerged within the real. 'When philosophy paints its grey in grey, then a shape of life has grown old. By philosophy's grey in grey it cannot be rejuvenated but only understood. The owl of Minerva spreads its wings only with the falling of the dusk.' ${ }^{15}$ We now know that these comments were made to avoid the work being censored. ${ }^{16}$ Hegel was articulating a political philosophy in opposition to both the feudal forms from which Germany was emerging and to the unrestrained capitalism of early 19th century Great Britainand this is how he was understood by his students. ${ }^{17}$ Rejecting the Hobbesian conception of humans as complex machines moved by appetites and aversions that underlay Anglophone political, social and economic thought, Hegel's political philosophy was based on a reformulation of Plato's conception of humans. In

14. Charles Radding, A World Made by Men: Cognition and Society, 400-1200 (Chapel Hill, NC: University of North Carolina Press, 1985).

15. T.M. Knox, transl., Hegel's Philosophy of Right (Oxford: Clarendon, 1952), p. 13.

16. See G.W.F. Hegel, Elements of the Philosophy of Right, Allen W. Wood, ed., and transl. H.B. Nisbet (Cambridge: Cambridge University Press, 1991), 'Editor's Introduction', p. viiiff. and 'Editorial Notes' p. 382f., n. 6 and p. 388f., n. 18. This is a new translation of Hegel's Philosophy of Right.

17. See John Edward Toews, Hegelianism: The Path toward Dialectical Humanism, 1805-1841 (Cambridge: Cambridge University Press, 1980). 
place of a tripartite soul, Hegel argued that people only transcend their biological immediacy and become self-reflexive and autonomous subjects through participating in three dialectical patterns, the dialectic of representation, the dialectic of recognition and the dialectic of labour. ${ }^{18}$ The dialectic of representation, operating primarily through language, engenders and is reproduced by the quest for knowledge and wisdom. The dialectic of recognition operating through moral notions engenders and is reproduced by the struggle for recognition. The dialectic of labour involves more than merely the quest to satisfy appetites; it is the dialectic through which people use and develop tools to transform nature.

Hegel's political philosophy is based largely on his analysis of the dialectic of recognition. ${ }^{19}$ For Hegel, this dialectic has been evolving along with the dialectic of representation and the dialectic of labour since the beginning of history. Its development has involved a sequence of stages in which recognition of people as free, responsible agents has become increasingly reciprocal and been extended to the entire population. While this development is associated with the social and psychological development of people (subjective spirit) and the development of consciousness in art, revealed religion and philosophy (absolute spirit), it has been crystallised in institutions (objective spirit), including the family, the market, corporations, law and government. Hegel ascribed significance to the property rights on which the market is based as a form of recognition. In this regard he appeared to be offering support to the mainstream of modernism. But at the same time Hegel was acutely aware and offered a penetrating analysis of the brutalising effects of the market as it operated in Britain, reducing people to day labourers, debasing and impoverishing them and at regular intervals throwing them into unemployment. ${ }^{20}$ For Hegel, the family through which people gain immediate recognition of each other as individuals is based on totally different principles than the market. The family is the realm of love and friendship in which individuals find themselves in others. ${ }^{21}$ Outside the family, in civil society, people must participate in the market to earn a living. This is the realm of the system of needs analysed by the economists, a realm in which people pursuing their particular interests help to satisfy the needs of others. But, argued Hegel (at a time when trade unions were illegal in Britain-they were not legalised until 1824 after a long campaign by Francis Place), the destructive effects of the concentration of wealth and power engendered by the market should be constrained by corporations, that is, trade unions and professional bodies which

18. See Leo Rauch, ed. and transl., 'Jena Lectures on the Philosophy of Spirit', in Hegel and the Human Spirit (Detroit: Wayne State University Press, 1983).

19. Still the best study of Hegel's political philosophy is Shlomo Avineri, Hegel's Theory of the Modern State (Cambridge: Cambridge University Press, 1972). See also Charles Taylor, Hegel and Modern Society (Cambridge: Cambridge University Press, 1979).

20. Knox, Hegel's Philosophy of Right, Sect. 243-246. See also Avineri, 'Labour, Alienation and the Power of the Market', in Hegel's Theory of the Modern State, p. 87ff. In this section, which shows the extent to which Hegel anticipated Marx's analysis of alienation, Avineri draws on Hegel's lesser-known writings.

21. Hegel's analysis of the forms of recognition has been explicated and developed in Axel Honneth, The Struggle for Recognition, transl. Joel Anderson (Cambridge, MA: MIT Press, 1996), esp. in 'Patterns of Intersubjective Recognition: Love, Rights, and Solidarity', ch. 5. 
are able to empower employees, and by the state. In this analysis Hegel is usually interpreted as simply describing modern society and distinguishing between day labourers and those who belong to corporations rather than showing how the 'liberal capitalism' of Britain could be overcome through corporations. ${ }^{22}$ But Hegel was not describing day labourers as an essential component of modern society but as condition to be overcome. As Hegel noted in relation to his discussion of poverty and efforts to deal with it, 'In the example of England we may study these phenomena on a large scale and also in particular the results of poorrates, immense foundations, unlimited private beneficence, and above all the abolition of the Guild Corporation. ${ }^{23}$ Through corporations people are recognised as more than instruments of production. They are empowered to gain recognition of their needs and their achievements, economic security, fulfilment and an identity through their work and political representation, and they are required for this reason. As Hegel put it:

In the Corporation, the family has its stable basis in the sense that its livelihood is assured there ... In addition, this nexus of capability and livelihood is a recognized fact with the result that the Corporation member needs no external marks beyond his own membership as evidence of his skill and his regular income and subsistence, i.e. as evidence that he is a somebody. It is also recognized that he is a whole that is itself an organ of the entire society, and that he is actively concerned in promoting the comparatively disinterested end of this whole. Thus he commands respect due to one in his social position. ${ }^{24}$

An individual deprived of such corporate recognition 'is without rank or dignity, his isolation reduces his business to mere self-seeking, and his livelihood and satisfaction become insecure. Consequently, he has to try to gain recognition for himself by giving external proofs of success in his business, and to these proofs no limits can be set. ${ }^{25}$ This anticipates Veblen's notion of conspicuous consumption.

The market and the corporations must in turn be supervised by the state which, as the embodiment of the will of the people, must ensure that the market and the corporations function in the universal interest. The state is the unification of the family principle and civil society, the unity of love or friendship with the principle of conscious and spontaneously active volition. Law is central to this. Hegel wrote of the state:

What dominates the State is the spirit of the people, custom and law. There man is recognized and treated as a rational being, as free, as a person; and the individual, on his side, makes himself worthy of this recognition by overcoming the natural state of his self-consciousness and obeying a universal, the will that is in essence and actuality will,

22. See for instance Avineri, 'Labour, Alienation ...', p. 153.

23. Knox, Hegel's Philosophy of Right, Sect. 245, p. 150.

24. Knox, Hegel's Philosophy of Right, Sect. 253. p. 153.

25. Knox, Hegel's Philosophy of Right, Sect. 253. p. $153 \mathrm{f}$. 
the law; he behaves, therefore, toward others in a manner that is universally valid, recognizing them-as he wishes others to recognize himas free, as persons. ${ }^{26}$

Those employed by the state, its civil servants, are required to 'forgo the selfish and capricious satisfaction of their subjective ends; by this very sacrifice, they acquire the right to find their satisfaction in, but only in, the dutiful discharge of their public functions. ${ }^{27}$ The state consists of an inward structure as a selfrelating development associated with constitutional law, and a relation to other states associated with international law, with each state participating in and being subject to the judgement of universal history.

\section{Realising the Social Democratic State}

The social democratic nation-state began to emerge out of capitalism in Germany and Austria towards the end of the 19th century, but developed more generally and more fully during and after the Great Depression and the Second World War. Sweden, Austria and Denmark led the way while USA dragged at the rear. This development has been associated with some further insights into its essential features. Habermas has invoked the reconstructive sciences, particularly the work of Piaget, to both explain and to illuminate the cognitive and ethical conditions of the modern social democratic state. ${ }^{28}$ Largely supporting the anthropological, phenomenological and psychological insights of Hegel, these sciences show the stages of socio-psychological development that individuals go through in such a way that the superiority of the highest stages can be appreciated. Piaget and his colleagues have shown the cognitive developments required both for participation in science and in order to be able to see things from others' points of view, to acquire a sense of justice and to negotiate a social consensus. Essentially, individuals develop cognitive structures which decentre them from their immediate experience, overcoming their egocentricism, enabling them to appreciate social rules and then, beyond this, to rationally evaluate social rules.

Further developing Hegel's insights, Axel Honneth has pointed out that recognition through the state involves both granting people respect as people, and esteeming them for their contribution to society as a whole. ${ }^{29}$ Such recognition involves granting rights to people, protecting them from injustices and enabling them to assert themselves without fear of retribution. It is also achieved through solidarity gained by enabling people to participate in society's projects and acknowledging their contributions to these and to society. The nation-state then

26. William Wallace and A.V. Miller, transl., Hegel's Philosophy of Mind (Oxford: Clarendon Press, 1971), Sect. 432, p. 172f.

27. Knox, Hegel's Philosophy of Right, Sect. 294, p. 191.

28. See Jürgen Habermas, Communication and the Evolution of Society, transl. Thomas McCarthy (London: Heinemann, 1976).

29. Honneth, The Struggle for Recognition, ch. 5. See also Charles Taylor, 'The Politics of Recognition' and Jurgen Habermas, 'Struggles for Recognition in the Democratic Constitutional State', in Amy Gutman, ed., Multiculturalism: Examining the Politics of Recognition (Princeton: Princeton University Press, 1994). 
becomes, as Benedict Anderson put it, an 'imagined community' where 'the nation is always conceived as a deep, horizontal comradeship'. ${ }^{30}$

How can such solidarity be achieved in a society in which economic relations are mediated by the market? This requires, using Bourdieu's terminology, a plurality of semi-autonomous fields, depending upon but transcending the economic field, through which recognition is accorded and values transcending the market sustained. ${ }^{31}$ Each of these fields (and sub-fields of these fields) come to have their own distinctive logic and symbolic capital (forms of recognition or status which enable those who have it to acquire more such capital). Within each field, good practices, actions and products are defined in terms of criteria generated and sustained within the field by the struggles for this capital. ${ }^{32}$ Bourdieu was particularly interested in how cultural fields, such as the field of art, the field of the novel, the academic field or the field of science have gained and retained such autonomy. For instance, scientists, competing with each other for the symbolic capital of the scientific field, come to be the judges of the contribution s of other scientists, and then according to what has come to be defined by scientists as good science, thereby perpetuating a struggle for objective knowledge. But to the extent that corporations, whether trade unions or professional bodies, have elevated people above day labourers, these also constitute fields transcending economic imperatives. Over and above economic criteria, they recognise and contest definitions of people's craftsmanship, professionalism and contribution to society as well as their needs and their dignity as people. The institutions of the state also generate such fields. Insofar as the legal field gains autonomy through the struggle of its participants for symbolic capital, a notion of justice and all that is required to uphold it is generated, contested and sustained as the core criterion for evaluating the decisions, actions and practices of its participants. Through the struggle by civil servants for symbolic capital, the civil service tends to become more than a mere instrument of politicians or business, generating its own distinctive criteria of the good to evaluate public institutions, political projects, civil servants and their actions. That is, the civil service itself

30. Benedict Anderson, Imagined Communities: Reflections on the Origin and Spread of Nationalism (London: Verso, 1983), p. 16.

31. While this may seem an odd way to interpret Bourdieu, I think Bourdieu's terminology can be used to reformulate Hegel's political ideas, overcoming the illusions of idealism and completing Marx's project of standing Hegel on his feet while simultaneously countering the post-modern skepticism of Foucault.

32. The clearest exposition by Bourdieu of his notion of the field is in Randal Johnson, ed., The Field of Cultural Production (Cambridge: Polity Press, 1993), ch. 1. Honneth typically but surprisingly misinterprets Boudieu as upholding utilitarian motifs and fails to appreciate the centrality of the struggle for recognition (or honour) in constituting fields (Axel Honneth, 'The Fragmented World of Symbolic Forms', in Charles W. Wright, ed., The Fragmented World of the Social (New York: S.U.N.Y. Press, 1995), ch. 11). What most commentators on Bourdieu fail to appreciate is that despite the savageness of Bourdieu's analyses of the way fields operate (apart from the scientific field) the worst scenario for him is the dissolution of all fields into the economic field; what is now happening. See Pierre Bourdieu, Acts of Resistance: Against the Tyranny of the Market, transl. Richard Nice (New York: The New Press, 1998), p. 37. 
becomes a field..$^{33}$ It is through this field that notions of integrity and impartiality and perspectives transcending all particular interests are generated, contested, redefined and sustained.

The autonomy of each field is related to and dependent upon the autonomy of other fields. The autonomy of the poetic field is dependent upon the autonomy of the literary field, and the autonomy of this field is augmented by the autonomy of the cultural, educational and journalistic fields to support discourse about literature and poetry. Most fields are dependent upon the autonomy of the legal field. All such fields, including the legal and political fields, are dependent upon the autonomy of the national field from pressures of other states and from the field of the global economy. The autonomy of the national field is dependent upon the autonomy of its own cultural, political and economic fields and also on global political and cultural fields such as those associated with the United Nations. The degree of autonomy of fields determines their ability to act as mediating forces between their members and external social, political and economic conditions and forces. ${ }^{34}$ It is the condition for them to critique these external conditions and forces.

\section{Dissolving Social Democracy}

Marx had already identified a central contradiction within the state as described by Hegel: the market, empowering the owners of the means of production who benefit from the market's expansion, tends to dominate everything else. Mystifying the nature of social relations, the market, through its own immanent dynamics and through the ruling class that it empowers to extend it, inexorably reduces all nature, all people, all institutions and consciousness itself, to instruments of the economy. Marx argued against Hegel that this was inevitable so long as production and exchange were based on market relations. But particularly after the Second World War, Hegel appeared to be right against Marx and the Marxists, as social democracy advanced to displace liberal democracy. The market was brought under control and employees gained some recognition as being more than day labourers selling their labour power as a commodity. The rise of the salariat and the professions was a measure of this. The growing power of the civil services to effect control over the economy and to act in universal interests was achieved through careful regulation of the nation's economic relations with other nations, and trade, flows of finance and foreign ownership were all regulated. By such means it appeared that the market might eventually be reduced to a mere instrument of the national community.

How was this control established? And why was it lost? The growth of the market was by no means as automatic as Marxists assume. The extension of the market in the 17th and 18th century was the outcome of power relations and power struggles. However, in the 19th century the new British dominated global economy that emerged from this provoked nationalist reactions engendering a

33. Not all civil services become autonomous in this way. The Swedish civil service was exemplary in this regard while the US civil service never gained autonomy.

34. Pierre Bourdieu and Loic J.D. Wacquant, An Invitation to Reflexive Sociology (Chicago: University of Chicago Press, 1992), p. 115. 
struggle between nations and their empires to control trade and finance to serve national economies. This control intensified in the 20th century in response to increasing economic instability and the rivalry and conflict between nations, generating nation-states that required a social democratic consensus to achieve the requisite unity of national purpose. It was in the environment created by these that various cultural, social and political fields were able to develop with considerable autonomy from the logic of the market.

The social democratic consensus prevailed up until the 1970s. But the growth of trade, the internationalis ation of finance and the growth of transnational corporations undermined the ability of even the most powerful states to control their economies. Transnational corporations and financial institutions could undermine any state that attempted to constrain the market to serve social ends by merely threatening to withdraw capital. But there was more involved than this. What we have seen is a successful series of power struggles by the proponents of the market's extension at all levels of society. These managers and their supporters promoted neo-liberal politicians and political parties and subverted their political opponents. They waged a massive public relations campaign, supported by transnational media moguls, to dissolve trade barriers, to remove restrictions on the flow of finance, to privatise public enterprises and to reduce taxes on corporations and on the wealthy. This has been accompanied by struggles within business corporations to increase the power of both shareholders and managers at the expense of stakeholders consumers, various employees and the people living where these corporations operate. There has been a concerted campaign to destroy trade unions and to reduce employees from respected trades people and professionals to day labourers without the economic security needed for them to exercise their democratic rights. There have also been successful power struggles within civil services, media and educational institutions and trade unions. What appears to have happened is that in social democracies power has been concentrated. And most of those whose power has been augmented, including members of supposedly left-wing political parties, administrators of public institutions and some trade unions, have come to identify themselves with a global managerial class and embraced neo-liberal ideology.

But if this were all there were to it, we would have seen far more political struggle. There was some, but what is astonishing was (and is) the lack of concerted opposition to transformations that have undermined or are undermining the security, income, wealth and health of the vast majority of people in these countries. There appears to be a cultural failure. The problem could be precisely those aspects of reality focussed on by post-modern theorists - the way people have been made into docile bodies, the way they now establish their identities through consumption rather than production, the way their conception of reality has been constructed by new media, and so on. However, there appears to be another dimension to the problem. The oligarchic structures of and consequent concentrations of power in social democratic states together with the subsequent atomising of human relationships, appear to have rendered people passive. To the extent that social democracy has not yet disintegrated, in Denmark for example, ${ }^{35}$

35. See Ash Amin and Damian Thomas, 'The Negotiated Economy: State and Civic Institutions in Denmark', Economy and Society, Vol. 25, No. 2 (May 1996), pp. 255-281. 
this can be explained as a consequence of the decentralised power structures in that society. My contention is that more than anything else it is this passivity that has engendered decadence, and this is the most important source of postmodernist culture. This is the dimension that needs to be examined more closely.

\section{Decadence of the Salariat}

Boris Frankel in From the Prophets Deserts Come has argued that radicals have rendered themselves politically impotent by embracing the ideas of post-modern theorists. ${ }^{36}$ But what I am suggesting is that the popularity of these theorists manifest deeper cultural transformations. The people who should have been the driving force for further subordinating the market to social goals, the people who were largely a product of the social democratic state, have given up the effort. At the same time they have acted in ways that have undermined the autonomy of the various social and cultural fields, including national fields, which had gained some autonomy from market imperatives, thereby augmenting the power of the global ruling class and the market. As Bourdieu noted of such people: 'In endeavouring to discredit every attempt to impose an autonomous principle of hierarchisation, and thus serving their own interests, they serve the interests of the dominant fractions of the dominant class, who obviously have an interest in there being only one hierarchy. ${ }^{37}$ This appears to be not a matter of choice but the disintegration of the ability to appreciate what is at issue. And many postmodern theorists with 'their denial of any objectivity to discourse, their inability to ground the resistance to power which they claim to articulate, and their denial of any coherence or initiative to the human subject', as Alex Callinicos characterised their views ${ }^{38}$ have legitimated such behaviour.

This disintegration becomes intelligible when we look at the transformations in cognitive culture that occurred in an earlier period of decadence, the decline of the Roman Empire. Radding showed that in this period people progressively lost their comprehension of a range of concepts that had been central to the Roman Republic. While this process had been described by Vico, Radding explained Vico's observations as a failure of people in the later Roman Empire to develop the higher phases of cognition identified by Piaget. ${ }^{39}$ It was a failure to develop the capacity to reflect on and transform their own cognitive processes associated with a failure to overcome their egocentricism (characteristic of the early phases of cognitive development) that made it difficult for them to see the world from the perspective of others. What we see among the people of the late Roman Empire, including the leading intellectuals of the era, is the disappearance of precisely the same features of social and individual life that post-modern theorists have been debunking, and partly for this reason, that are disintegrating in the present.

36. Boris Frankel, From the Prophets Deserts Come (Melbourne: Arena, 1992).

37. Bourdieu, 'The Field of Cultural Production', p. 41.

38. Alex Callinicos, Against Postmodernism (Cambridge: Polity Press, 1989), p. 6.

39. A succinct summary of Piaget's basic ideas has been provided in 'A Short Course in Piagetian Psychology', Radding, A World Made by Men, 'Appendix'. 
The first striking feature of late Roman thinking is the loss of a sense of the reality of institutions. The appreciation of institutions as enduring entities transcending the particular people who play roles within them, the relationship between roles within these institutions and the role of each institution in the functioning of society, requires an understanding of abstract nouns. Developing an appreciation of these had been an achievement of the Ancient Greeks, and then following them, the Romans of the Republic. As Radding noted, 'Classical philosophers had seen law as a social institution - an attitude closely related to their perceptions of society as an entity of which they themselves were members and toward which they had obligations. ${ }^{40}$ By contrast, St Augustine saw law as the creation of the Emperor and conceived relations between people purely in personal terms. Consequently, '[i]nstead of being based on mutual respect, the political order was thus regarded as something external to the will of the governed, a reality to which men had to accommodate their existence.' ${ }^{41}$ There was then no notion of an illegitimate ruler, a ruler who had overstepped the boundaries of his role as there had been for Cicero, since only personal relations were recognised. Correspondingly, monasteries were transformed from brotherhoods sharing a common life, that is, communities, to hierarchical organisation s in which monks were required to obey without question their abbots. No other relationships could be comprehended.

Margaret Thatcher's comment that there is no society, there are only individuals, clearly echoes this decadent frame of mind. This decadence was manifest in the way she treated the Conservative Party and Britain as a whole as hers, virtually giving away a large proportion of the nation's assets. But this attitude is endemic throughout Britain and throughout the former social democratic countries. In relation to government it is apparent in people who no longer see state institutions as people's creations, as a crystallisation of people's collective will from which they can expect just recognition, but as a collection of people imposing their will on others. This is associated with the disintegration of the various cultural fields that had reproduced and sustained this appreciation. Decadence is clearly evident in the politicians who gain control of social democratic political parties and, implementing neo-liberal economic policies, ignore the long history of those who created and sustained these parties in their quest for justice. It is also evident in the managers of public and business organisations who no longer conceive themselves as playing a role with rights and duties, but treat these organisations as instruments of their personal will, ignoring their role in society, sacking dutiful employees and then having themselves and their cohorts paid massive salaries, bonuses and other perks. Their malignant acquisitivenes $\mathrm{s}$ and conspicuous consumption on a massive scale bears out Hegel's predictions about how people will attempt to gain recognition when they no longer gain their identities as members of corporations. Correspondingly, it is evident in the response of employees and the general public to such behaviour. Most people appear unable to appreciate its illegitimacy or the significance of treating institutions such as hospitals, prisons and universities as enterprises for making money,

40. Radding, A World Made by Men, p. 44.

41. Ibid., p. 45. 
and their duty as citizens to censure and expel people who behave in this way. Although there are some exceptions, trade unions and professional bodies have lost both the will and their ability to defend the status of their members' callings, that is, the autonomy of their fields and their distinctive symbolic capital. In Australia, the National Tertiary Education Union, representing all academics, traded academic tenure for a few per cent pay increase, facilitating massive retrenchments of staff, the proliferation of managers and the elimination of collegial structures. The conditions for academics to judge students were undermined (there has been a catastrophic fall in standards as a consequence) and free and open enquiry and expression of ideas has been stifled. Other groups such as nurses and psychologists aim for professional recognition in order to increase their incomes, failing to appreciate that the essence of professionalism is a commitment to values transcending economic reward.

It is in this light that it is necessary to evaluate the hostility to public institutions of deconstructive post-modern theorists, particularly Foucault and those influenced by him. The only relationships acknowledged by such post-modern theorists, whether they are conformed to or rebelled against, are relationships of obedience by individuals to the actions of those occupying positions of power. Politics is reduced to efforts to free people from the constraints of institutions. There is no place to condemn incumbents as corrupt or to create new, more democratic institutions. By attacking institutions as such, post-modern theorists have enabled public institutions that were set up to serve the public to abrogate their responsibilities and made it easier to dismantle them entirely. Mental hospitals are an obvious example of this.

Closely associated with the loss of appreciation of the reality of institutions is the loss of the notion of responsible agents. St Augustine still had a strong sense of the significance of intention, and the difference between an act intended to have an effect from one in which the same effect was unintended. But his concern to point out the significance of this was evidence of how this distinction was being lost to his contemporaries. So while Augustine was concerned with the inner evolution leading to action, his rival Pelagius was concerned only with specifying appropriate behaviour for the conduct of the holy life. To generations after St Augustine the distinction between intention and outcome was completely lost. Law courts judged people solely on the outcomes of their actions, ignoring their intentions. Later, they judged them according to the correctness of their presentations to court. Finally they judged them by ordeal.

If this transformation is repeating itself in the present, it is easy to see why anti-Hegelian deconstructive post-modern theorists, post-structuralists such as Barthes, Lacan and Foucault, should have become so popular. Barthes, spelling out the implications of post-structuralism for the notion of the author, argued that '[1]inguistically, the author is never more than the instance of writing, just as $I$ is nothing other than the instance saying $I$ : language knows a "subject", not a "person", and this subject, empty outside of the very enunciation which defines it, suffices to make language "hold together", suffices, that is to say, to exhaust it." 42

42. Roland Barthes, 'The Death of the Author', in Stephen Heath, transl., Image, Music, Text (London: Fontana Press, 1977), p. 145. 
Denying both subjective intention and originality to the author, Barthes proclaimed, 'The text is a tissue of quotations drawn from innumerable centres of culture. ... [T] he writer can only imitate a gesture that is always anterior, never original. ${ }^{43}$ Lacan, conceiving the subject as generated in the movement from signifier to signifier, dismissed the role of intention and originality in life more generally. Foucault, granting a place to practices as well as language in the constitution of the subject, characterised the objective of his life's work 'to create a history of the different modes by which, in our culture, human beings are made subjects' ${ }^{44}$ People are made subjects by the institutions of the state and are thereby rendered ciphers of these institutions. The implication, as embraced by deconstructive post-modern theorists, is that Foucault wanted them unmade. ${ }^{45} \mathrm{By}$ denying that in becoming subjects people can acquire the ability to use language creatively and to criticise and reform the institutions of which they are part, deconstructive post-modern theorists have provided immense comfort to unoriginal, passive conformists who have eschewed any impulse to take responsibility for their own lives or for the future of society. All that can matter in this post-modern culture is outward conformity to certain behaviour patterns; that is, political correctness.

\section{The Decay of Intellectual Life}

According to Vico, 'as the popular states became corrupt, so also did the philosophies. They descended to skepticism. Learned fools fell to calumniating the truth. ${ }^{46}$ Radding has not only confirmed this to be the case in the last stages of the Roman Empire; through his study of the emergence of intellectual life in the Middle Ages he has shown what was involved in the creation of a culture committed to the pursuit of truth. A condition of this was the growth of education from the 9th century onwards, but this was not enough. What was more important was the collapse of political order in many parts of Europe in the 11th century that made appeal to outside authority impossible. So, '[t]hrown back on their own resources, people had to learn again the skills of persuading each other, and they responded by finding more skillful ways of reading texts, by insisting upon logical consistency as the foundation of argument, and by taking more account of the views of those with whom they disagreed. ${ }^{47}$ This stimulated the development of the ability of people to reflect upon concepts. People entered the realm of what Piaget called formal operations whereby they became capable of operating on their own cognitive operations. With the development of this cognitive stage, they could question concepts, generate new conceptual frameworks, use these to interpret the world and judge between rival ways of conceiving things. That is, they could think

43. Ibid., p. 146.

44. Michel Foucault, 'The Subject and Power', afterword to Hubert L. Dreyfus and Paul Rabinow, Michel Foucault (Brighton: The Harvester Press, 1982), p. 208.

45. Foucault later changed his mind on this.

46. Thomas Goddard Bergin and Max Harald Fisch, transl., The New Science of Giambattista Vico (Ithaca: Cornell University Press, 1984), Sect. 1102, p. 423.

47. Radding, A World Made by Men, p. 256. 
dialectically. With the capacity to use abstract nouns, the reality of community was again recognised and law and politics became affairs of the community to be reflected upon and discussed and argued about. And as people overcame their egocentricism, nature became an object of interest to be understood as a realm in its own right. And they became interested in history and writing histories.

The decline of intellectual life at the end of the Roman Empire was characterised by the disintegration of these capabilities (capabilities that had emerged during the Roman Republic). Although people continued learning the classics, they lost the ability to engage in disputes and to see things from the perspective of others and, at the same time, lost the ability to manipulate concepts. Commenting on the degeneration of education, Radding noted:

[W] hen scholars approach works with the intention of reproducing the words of the masters instead of their thoughts, they miss the internal connections between ideas and the facts they were meant to explain. In the last empire what resulted were handbooks full of isolated comments, often torn out of context with crucial conclusions and steps of logic omitted. ... Instead of classical learning being used to understand the world, and writing used to communicate understanding, both had become kinds of conspicuous consumption, ornaments and emblems of the leisured life. Ideas themselves had become, in Piaget's phrase, a thing external to the mind. ${ }^{48}$

Nature came to be seen as a realm dominated by supernatural forces and all curiosity to understand nature itself disappeared. The quest for truth about a world independent of us, characteristic of societies in their generative stages, evaporated. Correspondingly, people lost their ability to construct narratives and to situate themselves in the world historically.

What we now see is a similar decay of intellectual life. While there are a variety of reasons for this, leading intellectuals such as Foucault, Lacan, Derrida and Feyerabend, at least as they have been interpreted by their lumpen-intellectual followers, have 'calumniated the truth', and Baudrillard has been interpreted as denying the distinction between appearance and reality. ${ }^{49}$ The ideas of these intellectuals would be of little significance in themselves if they were marginal thinkers; what is significant is that they have become such celebrities. While such thinking has not completely dominated, with the support of such deconstructive post-modernists it has permeated intellectual culture and often marginalised its opponents.

This is most evident in the humanities, the disciplines that reflect upon culture. In an essay written on the state of literary criticism in USA, and Bulgarian/French literary theorist Tzvetan Todorov wrote of the dominant ideas:

'Post-structuralism' has developed along two major lines .... . The first - and the more dogmatic and elaborate—of the two main types is

48. Radding, A World Made by Men, p. 53f.

49. Baudrillard can also be interpreted as trying to expose our loss of ability to make this distinction. 
called 'deconstruction'. Oversimplifying somewhat, we might say that deconstruction renders the earlier question ['What does this text mean?'] moot by invariably answering: 'Nothing at all'. The second type of poststructuralism, more cheerful but also more naïve, is sometimes known by its advocates as 'pragmatism'. Pragmatism renders the question meaningless by replying: 'Anything whatsoever'. In the wake of either response, obviously, the question can hardly be raised again; it seems preferable to go on to something else. ${ }^{50}$

Students who chose to study literature to understand and orient themselves, to reveal what is most valuable in life, to understand their own and others' points of view, to envisage new possibilities and to refigure the narratives of their lives, have been left in the lurch by most of their teachers. They are told to make do with the pleasure of 'transgressive readings' of the text. Cultural Studies is, if anything, even worse. Alan Sokal demonstrated the state of this 'discipline' with his hoax paper, 'Transgressing the Boundaries: Toward a Transformative Hermeneutic of Quantum Gravity'. This was published by the pre-eminent cultural studies journal in USA, Social Text. The paper consisted of a mixture of genuine and spurious descriptions of developments in science ornamented with quotations taken out of context from Derrida and other post-modern theorists. ${ }^{51}$ The situation is not much better in the humanities disciplines, relatively free of the influence of post-modern theorists. Alasdair MacIntyre described the state of Anglophone philosophy:

We ... detach ... what we take to be distinct and isolable topics from the systematic metaphysical contexts in which our predecessors' discussions of these topics were embedded. ... [T]his is achieved by the fragmentation of systems into more or less piecemeal treatments of particular problems. These institutionalized patterns and habits enable us to avoid any confrontation between the systematic claims of the major philosophies of the past and our own beliefs, political, religious, moral or cosmological. ${ }^{52}$

No issue is ever resolved by these practices. Analytic philosophy is characterised by a succession of fashions (or more precisely, intellectual parlour games), each indifferent to or hostile to the fashion that immediately preceded it. With few exceptions, such philosophers have no interest in understanding the work of other philosophers, past or present, or to communicate their ideas to people outside their own little circles. What the humanities have in common is the loss of the capacity to put works or to situate one's own work in an historical perspective.

50. Tzvetan Todorov, Literature and its Theorists, transl. Catherine Porter (Ithaca: Cornell University Press, 1987), p. 183.

51. Sokal, Social Text, 46/47 (spring/summer 1996), pp. 217-252. Sokal with Jean Bricmont has extended his attack on post-modern cultural theory in Intellectual Impostures (London: Profile Books, 1998 [1997]).

52. Alasdair MacIntyre, 'Philosophy: Past Conflict and Future Direction', Proceedings and Addresses of the American Philosophical Association, (September 1987), p. $82 \mathrm{f}$. 
It is generally assumed that the natural sciences, and most importantly, physics, are intact. This is questionable. While there are still pockets of creativity within science, since the 1930s, scientists in general have become steadily more dogmatic and less interested in understanding the nature of reality, and science has increasingly been reduced to an economic and political instrument. ${ }^{53}$ This dogmatism revealed itself in the early 1950s in the response to the work of the physicist David Bohm when he proposed a theory that would coherently explain quantum phenomena. In a recent biography of Bohm, David Peat described the response to Max Dresden who had read the paper and asked for Robert Oppenheimer's opinion of it: "We consider it juvenile deviationism," Oppenheimer replied. No, no one had actually read the paper-“we don't waste our time." ... Oppenheimer went so far as to suggest that "if we cannot disprove Bohm, then we must agree to ignore him". ${ }^{54}$ With the exception of Richard Feynman, who apparently accepted the theory, and Einstein who did not accept it (but still regarded Bohm as his intellectual successor), this was the response of the vast majority of physicists. This typifies the attitude towards scientists who question or oppose the prevailing metaphysical assumptions, Joseph Needham, C.H. Waddington and Ilya Prigogine being the most eminent examples. And corresponding to what appears to be an increasing level of egocentricism in culture, there is less and less interest by the general public in understanding nature as an independent reality.

The consequence of the marginalisation of scientists grappling with the more fundamental questions about the nature of physical existence, of life and what it is to be human, is that the Hegelian conception of humans as creative social beings able to achieve reciprocity of recognition and to transform the condition s of their existence, appears to be an illusion. The prevailing view of nature, that which emerged from the 17th to the 19th century, is still that it is a mechanical order of matter in motion. This supports the Hobbesian conception of humans as complex machines or information processing cyborgs moved by appetites and aversions to struggle for survival and domination, the conception of humans that is the foundation of orthodox economics and social Darwinism. With developments in the humanities and the natural sciences that lent support to the view of humans required to sustain social democracy (or any form of genuine democracy) undermined by the decay of intellectual life, social democracy has been construed as an unnatural, short-lived aberration.

\section{Post-modernism, Neo-liberalism and Decadence}

We can now see why post-modernism has been associated with the revival of neo-liberal ideologies. The emancipation promoted by post-modernists is nothing more than a railing against any form of constraint. Their hostility to institution $\mathrm{s}$ and to cultural fields manifests an increasing egocentricism characteristic of a

53. On this, see David Dickson, The New Politics of Science (Chicago: University of Chicago Press, 1988).

54. F. David Peat, Infinite Potential: The Life and Times of David Bohm (Reading: MA: AddisonWesley,1997), p. 133. 
failure in cognitive development. Political correctness as a form of political assertion focuses on the superficial aspects of interpersonal relations and tends to be concerned with the observance of correct behaviour rather than people's deeper beliefs and how these have been arrived at. While post-modern politics is often aligned with just causes, including environmental causes, there is no interest in defending the notion of justice or in understanding and effectively arguing against opposing views. While Lyotard argued that the defining characteristic of the post-modern condition is an incredulity towards meta-narratives, a more accurate way of characterising the condition is one in which the sub-classes that emerged out of and benefited from social democracy have lost the plot. More fundamentally, they have lost the ability to construct or reconstruct or even appreciate broader narratives about society and humanity. While post-modern theorists claim this is somehow liberating, in doing so they are merely echoing the attitudes that come to the fore in all periods of decadence.

With the triumph of neo-liberalism and a globalised market devastating human communities and the world's ecosystems, the question arises whether social democracy can be revived and then developed to confront environmental issues. Can transnational corporations be brought under control? Given that most countries have allowed the self-reliance of their economies to be undermined, this would be a massive, though perhaps not impossible task. What is more important is the loss of will to re-establish national control over economies. Here the problems are immense. Throughout the world political parties supposedly on the left have been captured by neo-liberals. And this is a manifestation of the biggest problem of all, the decadence of the left and of the sub-classes that had most reason for upholding social democracy.

There are a number of factors leading to this decadence-the failure of people to properly overcome the corrosive effects of the market, the corrupt nature of the fields that have gained some autonomy from the market, and the failure of the proponents of social democracy to properly understand the principles on which it was founded and what was required to reproduce and advance it. However, it would appear from the parallels between the late Roman Empire and the social democratic state that the biggest factor was the disintegration of participatory democracy and the concentration of power. People as members of institution s were increasingly disempowered and rendered passive recipients of whatever social benefits there were and it was this that engendered decadence.

\section{Conclusion}

There are two lessons to be drawn from post-modernism. The first is that a social order which does not involve all people as active participants in policy formation and implementation, that is, a social order which is not genuinely democratic, will tend to stagnate, breed decadence and lose all that had been gained. Social democracy is unlikely to be revived from above through efforts by radical groups to regain control of left-wing parties. Such political parties were only ever effective forces for justice when they were expressions of broader, democratic social movements with the power to control their representatives. A revival of social democracy will only be possible (if at all) through a struggle by people for 
immediate control over their lives, that is, through a struggle for direct democracy (or what Benjamin Barber called 'strong democracy') in society's institutions. ${ }^{55}$

The second lesson is that the rejection of all institutional and traditional constraints should not be confused with the struggle for freedom. If people decide that in a world of globalised markets, social democracy is a lost cause, and then strive to create confederations of largely self-sufficient, democratic city-states in place of markets, success will require the development of people's potential to transcend their egocentricism, engage in social relations based on reciprocity of recognition, and take responsibility for their actions. It will involve the creation of institutions and the appreciation of them as transcending each of their members and as human creations that, as such, can be criticised and transformed. ${ }^{56}$ Genuine freedom, as Hegel recognised, is achieved by participating in rational institutions, not by undermining them. However, truly rational institutions, institutions that fully recognise the creative potential of people, will be institutions of participatory democracy.

55. Benjamin Barber, Strong Democracy: Participatory Politics for a New Age (London: University of California Press, 1984).

56. The failure to appreciate the transcendence by institutions of individuals can lead to mob rule rather than participatory democracy. The problems to which participatory democracy is prone is brilliantly described in Benjamin R. Barber, The Death of Communal Liberty: A History of Freedom in a Swiss Mountain Canton (Princeton: Princeton University Press, 1974). 